\title{
Examining the Changes in Beliefs of Preservice Mathematics Teachers Attending the Pedagogic Formation Program about Teacher and Students Roles
}

\author{
Davut Köğce ${ }^{1, *}$ \\ ${ }^{1}$ Faculty of Education, Niğde Ömer Halisdemir University, Niğde, Turkey \\ *Correspondence: Department of Mathematics and Science Education, Faculty of Education, Niğde Ömer Halisdemir \\ University, Niğde, Turkey. E-mail: kogced@gmail.com
}

Received: November 14, 2019

Accepted: December 20, 2019 Online Published: April 20, 2020

doi:10.5430/wje.v10n2p89

URL: https://doi.org/10.5430/wje.v10n2p89

\begin{abstract}
This study aimed to identify the beliefs of preservice mathematics teachers receiving formation program as undergraduates or graduates in the Faculty of Science and Letters about teacher and student roles in the classroom setting and to explore how their beliefs changed at the end of the program. The research was conducted in the qualitative research design. The data were collected with a form of three open-ended questions asked to the preservice mathematics teacher attending the formation program in the faculty of education in the fall term of 2014-2015 academic year. The data were collected by applying this questionnaire to the preservice teachers at the beginning and end of the formation program. The answers of the preservice teachers were analyzed by classifying thematically by similarity and difference using the MAXQDA 11 qualitative data analysis software. While the preservice teachers had had beliefs placed somewhere between absolute knowing and transitional knowing about both teacher and student roles before the formation program, these beliefs were transformed into ones placed somewhere between transitional knowing and independent knowing after the formation program. This result indicated how important the pedagogical formation programs are for preservice teachers.
\end{abstract}

Keywords: Preservice mathematics teachers, teacher's role, student's role, beliefs of teaching and learning

\section{Introduction}

In Turkey, the constructivist approach is adopted in the mathematics curricula implemented in schools by the Ministry of National Education. With the change of this new approach, roles of teachers and students in the classroom setting have also changed. In the traditional approach, teacher is an authoritarian person who has an unpermissive temperament and is strictly disciplined (Bozdoğan, Aydın, \& Yıldırım, 2007), knows everything and controls the source of information and all phases of the learning-teaching process and has the right to speak in the classroom (Arslan \& Eraslan, 2003; Güneş, 2008). In the constructivist approach, teacher is a person who develops and implements activities, who questions, guides the students, makes them think and discuss, can work together, evaluates, gives students more options and responsibilities during their learning and improves himself/herself professionally all the time (Akpınar, 2010; Baki, 2008; Güneş, 2008; Morgil \& Yılmaz, 1999).

For achieving the basic skills and goals designated in mathematics curricula, it is expected from in-service and preservice mathematics teachers to master the learning and teaching approach of the curriculum and to embrace their roles regarding learning and teaching (Ersoy, 2006). How students structure their own knowledge actively during the learning and teaching process is possible when teachers prepare appropriate learning environments and guide them in these environments. And this depends on the fact that change in the new program approach is definitely adopted by teachers. In this sense, it is of great importance that preservice mathematics teachers are trained in accordance with the main goals and philosophical approach of the high school mathematics curriculum during their undergraduate education. To this end, students in faculties of education take courses related to field teaching in addition to the field courses during the undergraduate education and become entitled to be teachers. On the other hand, students attending the mathematics departments in faculties of science and letters can take the courses related to field education in faculties of education by courtesy of Council of Higher Education after having completed the undergraduate 
education or in the last year of university to have certificate of pedagogical formation and qualify to become teachers (Özoğlu, 2010).

In the literature, knowledge that should be possessed by a teacher is described as a complex mental structure involving multiple elements in regard to teaching. Shulman (1987) classified and defined teacher's knowledge structure in seven categories: content knowledge, general pedagogical knowledge, curriculum knowledge, knowledge of learners and their characteristics, knowledge of educational contexts, knowledge of educational ends, purposes and values, and pedagogical content knowledge. Fennema and Franke (1992) state that the teacher should have the knowledge of recognizing his/her students (knowledge about students' thinking and learning processes), content knowledge (mathematical concept, procedural and problem-solving knowledge) and pedagogical knowledge (knowledge of effective planning, classroom management, ensuring student motivation, curriculum). Otherwise, subjects in education will not be able to be fully taught by the teacher who does not possess content and field education knowledge or any of them, and therefore, the student achievements will be adversely affected (Huckstep et al., 2002). Similarly, Goulding et al. (2002) stated that preservice teachers who have poor content knowledge and field teaching knowledge would also have poor instructional planning skills. Irez (2007) states that teachers' belief systems about teaching affect their course planning, instructional decisions and classroom practices. Similarly, Nespor (1987) states that beliefs consist of personal experiences, and therefore, teachers' beliefs may develop as a result of in-school and out-of-school experiences and are the most determinant factors in their decisions throughout their lives.

From the educational and instructional perspective, teachers' beliefs and thoughts about learning and teaching have an important place in the learning and teaching process as they have influence on their perceptions (Pajares, 1992; Thompson, 1992). Hence, beliefs and thoughts of preservice teachers attending the mathematics formation program about teacher and student roles in the classroom setting can affect how they teach in accordance with the ends and philosophical approaches of the high school mathematics curriculum by using the abovementioned knowledge structures. Nespor (1987) states that it would not be possible to develop a new belief system about a given matter without changing individuals' current beliefs about it.

Although there have been studies on pedagogical formation in the subjects of problem of teacher training and pedagogical formation (Yıldırım \& Vural, 2014), preservice teachers' metaphors of pedagogical formation (Yapıc1 \& Yapıc1, 2013), faculties of science and letters and formation program (Ünüvar, 2012), pedagogical formation students' opinions on teaching practice (Tepeli \& Caner 2014), pedagogical formation and faculty of education students' attitudes toward teaching profession (Bahçeci et al., 2015), and pedagogical formation students' self-efficacy and metaphorical perceptions in regard to teaching (Çocuk, Yokuş, \& Tanrıseven, 2015) in Turkey, no study has been performed with preservice teachers attending the formation program in general and preservice mathematics teachers receiving formation in particular on their beliefs and thoughts on teaching and how their beliefs and thoughts changed at the end of the formation program. Since preservice mathematics teachers' beliefs about teacher and student roles will directly affect their in-service instructional planning and practices, investigation of their beliefs and thoughts about teacher and student beliefs is essential. Results to be achieved in this study will explore how the formation program changed preservice teachers' thoughts about learning and teaching and will shed light on whether pedagogic formation is required for educational activities. Since teachers' preservice experiences are very effective in the development of their beliefs about learning and teaching and there is a close relation between their beliefs and practices (Wilkins \& Brand, 2004; Frykholm, 2003; Ball, 1998; Lloyd \& Wilson, 1998), results of this study should provide useful information for the field of teacher training (Boz \& Uzuntiryaki 2006; Sinan \& Akyüz, 2012). The results will also guide faculty members who teach in the formation program in regard to learning and teaching approaches of preservice teachers. Moreover, examining the change in beliefs and thoughts about teacher and student roles among preservice teachers attending the mathematics formation program will contribute to studies on mathematics teaching and the improvement of student learning and even the educational studies to be performed for students. Another reason why such study was performed is that there is no study observed to be investigating the opinions on teacher and student roles in the classroom setting among preservice mathematics teachers who are studying in faculties of science and letters or are graduates. Another reason is that of the preservice mathematics teachers who are the sample of this study, the preservice teachers who had first received pedagogic formation in the faculty of education exhibited behaviors characteristic of the traditional teacher and student roles in the practices they performed for the courses of special teaching methods and school experience.

Thus, the main objective of this study was to identify what beliefs and thoughts the preservice teachers attending the mathematics formation program had about teacher and student roles in the classroom setting and what kind of a change occurred in these beliefs and thoughts at the end of the formation program. The following are subproblems 
for which answers were sought in accordance with the main objective:

At the end of the formation program, regarding the classroom setting;

1- How did the preservice mathematics teachers' beliefs and thoughts about teacher roles change?

2- How did the preservice mathematics teachers' beliefs and thoughts about student roles change?

\section{Method}

This study used the qualitative research design. Qualitative research ensures that data are read over and over to be divided into codes and categories based on their similarities and differences and research results are presented (Merriam, 1998; Çepni, 2018; Karasar, 2019; Yıldırım \& Şimşek, 2018).

\subsection{Participants}

The sample of the study was composed of preservice teachers attending the formation program (94 preservice teachers at the beginning, 52 preservice teachers at the end of the program) in the department of mathematics teaching in the faculty of education at a public university in the academic year of 2014-2015.

\subsection{Instrument}

The data in the study were collected with a form of three open-ended questions prepared in accordance with the aim of the research. The open-ended questions allowed preservice teachers to express the reasons for their answers and reflected the way they thought of teacher and student roles in the classroom setting (Gronlund \& Linn, 1990). This is why open-ended questions were utilized as data collection instrument. While the first two questions asked the preservice teachers to explain their thoughts about teacher and student roles in the classroom setting in detail, the third question asked them to draw their opinions and thoughts about teacher and student roles in the classroom setting. This questionnaire was submitted to the opinion of two field education experts and was finalized on the basis of their opinions and suggestions to achieve its content validity.

The questions in the instrument are as follows:

1- Which roles should a teacher have in the classroom setting when teaching mathematics? What do you think of teacher's role? Please explain your opinion in detail.

2- Which roles should a student have in the classroom setting when learning mathematics? What do you think of student's role? Please explain your opinion in detail.

3- Please make a detailed drawing that reflects teacher and student roles in the classroom setting with the mathematics teaching in mind.

\subsection{Data Collection and Analysis}

The data in the study were collected in two stages at the beginning and end of the formation program. The reason why the instrument was applied at the beginning of the formation program was to explore what beliefs and thoughts the preservice mathematics teachers had had about teacher and student roles in the classroom setting before taking any of the courses in the pedagogic information (in other words, their current position on the subject). The reason why the instrument was also applied at the end of the formation program was to identify preservice mathematics teachers' beliefs and thoughts about teacher and student roles in the classroom setting at the end of the program and to compare them with the data achieved in the first application for determining what kind of a change occurred in their beliefs and thoughts at the end of the program.

After the application of the questionnaire, form of each preservice teacher was given a number. For example, "PT1" represents the Preservice Teacher 1 . Next, answers of the preservice teachers to the open-ended questions were scanned as images and transferred into digital medium. The data were subjected to MAXQDA 11 qualitative data analysis software, and "data coding" of data analysis techniques was utilized (Yıldırım \& Şimşek, 2018).

To analyze the obtained data in a reliable way, first, the answers given to the questions by 10 randomly chosen preservice teachers were classified and analyzed categorically according to their similarities and differences separately by the researcher and a field education expert (Merriam, 1988; Yin, 1994). The degree of agreement of the coding performed by the researcher and the field education expert was calculated with the formulation "Reliability= (Number of agreed categories)/ (Total number of agreed and disagreed categories)" (Miles \& Huberman, 1994). The reliability degree regarding the agreement between the analyses performed individually by the researcher and the field education expert was calculated to be 0.92 for teacher roles and 0.88 for student roles. Miles and Huberman 
(1994) state that agreement between the two coders being 0.70 and above is sufficient for reliability. Accordingly, it was decided that the agreement between the coders was reliable.

Table 1. Epistemological Reflection Model

\begin{tabular}{|c|c|c|c|c|}
\hline Dimensions & 1. Absolute Knowing & 2. Transitional Knowing & 3. Independent Knowing & 4. Contextual Knowing \\
\hline 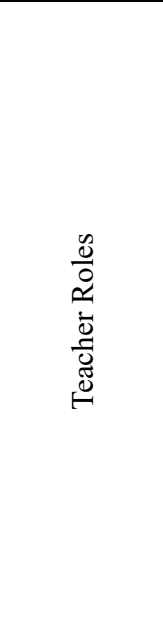 & $\begin{array}{l}\text {-Present the } \\
\text { information properly, } \\
\text {-Make sure that } \\
\text { students understand } \\
\text { the subject, } \\
\text {-Ensure that students } \\
\text { rehearse what the } \\
\text { teacher told them, } \\
\text {-Keep students awake, } \\
\text { attract their attention } \\
\text { to the course. } \\
\text {-Establish authority }\end{array}$ & $\begin{array}{l}\text {-Use appropriate methods } \\
\text { to facilitate } \\
\text { comprehension, } \\
\text {-Use methods to help } \\
\text { students put what they } \\
\text { have learned into practice, } \\
\text {-Ask thought-provoking } \\
\text { questions to ensure } \\
\text { participation in the } \\
\text { course, } \\
\text {-Give students the } \\
\text { opportunity to express } \\
\text { their thoughts openly and } \\
\text { listen to them patiently, }\end{array}$ & $\begin{array}{l}\text {-Support independent } \\
\text { thinking of the students, } \\
\text {-Encourage students to } \\
\text { exchange opinions and } \\
\text { explore the information, } \\
\text {-Guide the students, } \\
\text {-Provide feedback to } \\
\text { improve student } \\
\text { performances, } \\
\text {-Offer environments to } \\
\text { improve students' } \\
\text { problem-solving skills, }\end{array}$ & $\begin{array}{l}\text {-Help students put the } \\
\text { information into } \\
\text { practice, } \\
\text {-Encourage students to } \\
\text { discuss their opinions } \\
\text { critically, } \\
\text {-Offer opportunities for } \\
\text { students and teacher to } \\
\text { criticize each other, } \\
\text {-Enable students to } \\
\text { prepare projects for the } \\
\text { solution of daily-life } \\
\text { problems, }\end{array}$ \\
\hline 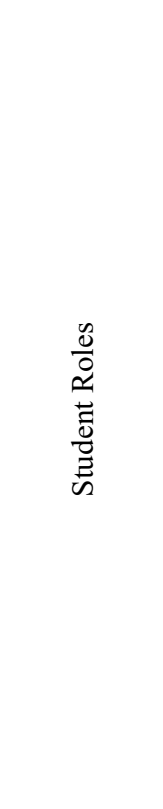 & $\begin{array}{l}\text {-Receive information } \\
\text { from the teacher, } \\
\text {-Listen to the teacher } \\
\text { and note down what is } \\
\text { told, } \\
\text {-Abide the authority, }\end{array}$ & $\begin{array}{l}\text {-Comprehend the } \\
\text { information rather than } \\
\text { memorizing it, } \\
\text {-Learn and interpret } \\
\text { where a formulation or a } \\
\text { piece of information } \\
\text { comes from, why it is like } \\
\text { that rather than } \\
\text { memorizing it, } \\
\text {-Participate in discussions } \\
\text { during the course and } \\
\text { explain his/her own ideas } \\
\text { and thoughts, } \\
\text {-Ask the teacher what } \\
\text { he/she does not know and } \\
\text { to explain it, } \\
\text {-Answer teacher's } \\
\text { questions, }\end{array}$ & $\begin{array}{l}\text {-Explore himself/herself } \\
\text { and structure, develop } \\
\text { and share his/her own } \\
\text { opinion with others, } \\
\text {-Take others' thoughts } \\
\text { when making an } \\
\text { evaluation about a } \\
\text { subject, }\end{array}$ & $\begin{array}{l}\text {-Create a problem } \\
\text { status, } \\
\text {-Exchange and compare } \\
\text { opinions, } \\
\text {-Think critically about a } \\
\text { situation and question } \\
\text { it. }\end{array}$ \\
\hline
\end{tabular}

These categories formed by the researcher and the field expert were reviewed by them together to clarify the similar categories, and different categories were discussed to achieve consensus (Merriam, 1988; Yin, 1994). The answers given by the remaining preservice teachers were categorically analyzed by the researcher alone in terms of their similarities and differences. The codes and themes which were created once the analysis of all the data was completed were submitted to the review by the same field education expert and finalized according to the recommendations. Their percentage-frequency values were presented in tables (Table 2-Table 3). Next, the drawings made by the preservice teachers about teacher and student roles were associated with the codes and themes presented in Table 2 and Table 3 and classified, and they were submitted to the opinion of the same field expert to finalize the association of the drawings with the codes and themes (See Table 4 and Table 5).

In addition, these codes created about teacher and student roles were associated with the rubric developed by Aydin (2010) on the basis of Baxter Magolda's (1992) Epistemological Reflection Model to identify the beliefs and thoughts of the preservice teachers about teacher and student roles. To see how the preservice teachers' beliefs and philosophies about teacher and student roles changed at the end of the formation program, the changes in the rates of 
expression of the codes given in Table 2 and Table 3 were compared. The beliefs and philosophies of the preservice mathematics teachers about teacher and student roles were identified in consideration of the codes (codes expressed by $10 \%$ and above) achieved in regard to teacher and student roles in the classroom setting.

The perceptions in this model were ascendingly classified in four different levels of absolute, transitional, independent, and contextual knowing. According to this model, individuals of the first level believe that knowledge is absolute and presented by a single authority. Individuals of the second level believe that experts cannot know everything and they doubt the absoluteness of knowledge. Individuals of the third level believe that knowledge is not absolute, there can be independent ideas and personal thoughts can be on the same level with expert opinions. Individuals of the final level believe that knowledge is in constant change and development and can be recreated with new contents (Whitmire, 2003; Deryakulu, 2004; Brownlee, 2001; Aydın 2010; Demir \& Akınoğlu 2010).

Table 1 summarizes the model's dimensions about teacher and student roles

The findings achieved in the data analysis were given in tables with their percentage and frequency values. Percentage values may exceed $100 \%$ because the answers of some of the preservice teachers were placed under multiple codes. Furthermore, the data concerning each code were presented in the findings section with examples from preservice teachers' own answers to the questions.

The validity and reliability measures required for qualitative research were taken in this study. To achieve internal validity, the preservice teachers were asked to answer each question sincerely in the process of applying the data collection instrument. For the external validity, the findings were presented in consistency with the research questions. To achieve the external reliability, the codes and categories used in the data analysis were defined, and detailed explanation was made on data collection and analysis methods (Yıldırım \& Şimşek, 2018). For the internal reliability, a field education expert was asked for opinion, and the achieved data were descriptively presented in detail.

The acronyms given in the tables in the findings sections are as follows: “TT(no): Traditional Teacher no, TCT(no): Traditional and Constructivist Teacher no, CT(no): Constructivist Teacher no, TS(no): Traditional Student no, TCS(no): Traditional and Constructivist Student no, CS(no): Constructivist Student no, D(no): Drawing no".

\section{Findings}

The percentage and frequency values of the codes achieved from the preservice mathematics teachers' statements on teacher roles in the classroom setting before and after the formation program are given in Table 2.

According to Table 2, the preservice teacher opinions on teacher roles in the classroom setting were grouped in three different themes of "Traditional Teacher", "Traditional and Constructivist Teacher", and "Constructivist Teacher".

Regarding the opinions in the theme of traditional teacher, of the participants, $43.6 \%$ before the formation program and $9.61 \%$ after the program believed that teacher's role in the classroom is to establish authority or discipline; $42.6 \%$ before the program and $9.61 \%$ after the program believed that it is to relay and teach information; and $23.4 \%$ before the program and $3.84 \%$ after the program believed that it is to set example for students. While being in low rates, the preservice teachers stated that teacher's role is to answer student questions $(2.13 \%$ before the formation program, $3.84 \%$ after the program) and to be sympathetic to students (2.13\% before the program, $1.92 \%$ after the program). 
Table 2. Distribution of Opinions on Teacher Roles

\begin{tabular}{|c|c|c|c|c|c|c|c|c|}
\hline \multirow[t]{2}{*}{$\stackrel{\mathscr{\Xi}}{\mathbb{E}}$} & \multirow{2}{*}{ 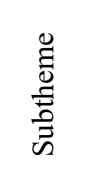 } & & \multirow[t]{2}{*}{ Codes } & \multirow{2}{*}{$\begin{array}{l}\text { Levels of Baxter } \\
\text { Magolda's (1992) } \\
\text { Epistemological } \\
\text { Reflection Model }\end{array}$} & \multicolumn{2}{|c|}{$\begin{array}{c}\text { Before } \\
\text { Formation } \\
\text { Program }\end{array}$} & \multicolumn{2}{|c|}{$\begin{array}{c}\text { After } \\
\text { Formation } \\
\text { Program }\end{array}$} \\
\hline & & & & & $\mathrm{f}$ & $\%$ & $\mathrm{f}$ & $\%$ \\
\hline \multirow{5}{*}{ 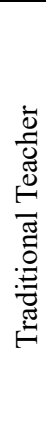 } & \multirow{5}{*}{ 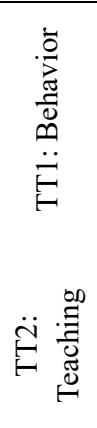 } & TT1.1 & $\begin{array}{l}\text { Be sympathetic (mother-father, } \\
\text { older-younger sibling) }\end{array}$ & Absolute & 2 & 2.13 & 1 & 1.92 \\
\hline & & TT1.2 & Establish authority or discipline & Absolute & 41 & 43.6 & 5 & 9.61 \\
\hline & & TT1.3 & Set example for students & Absolute & 22 & 23.4 & 2 & 3.84 \\
\hline & & TT2.1 & Relay and teach information & Absolute & 40 & 42.6 & 5 & 9.61 \\
\hline & & TT2.2 & Answer student questions & Absolute & 2 & 2.13 & 2 & 3.84 \\
\hline \multirow{16}{*}{ 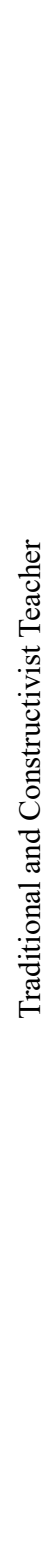 } & \multirow{7}{*}{ 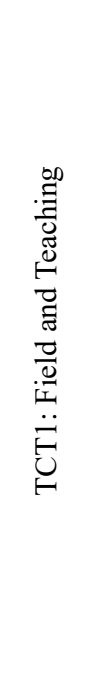 } & TCT1.1 & Ask students questions & $\begin{array}{l}\text { Transitional } \\
\text { Knowing }\end{array}$ & 2 & 2.13 & 8 & 15.3 \\
\hline & & TCT1.2 & Ensure student readiness & $\begin{array}{l}\text { Transitional } \\
\text { Knowing }\end{array}$ & 1 & 1.06 & 15 & 28.8 \\
\hline & & TCT1.3 & Provide reinforcers and feedbacks & $\begin{array}{l}\text { Independent } \\
\text { Knowing }\end{array}$ & 1 & 1.06 & 40 & 76.9 \\
\hline & & TCT1.4 & Come to the class prepared & $\begin{array}{l}\text { Transitional } \\
\text { Knowing }\end{array}$ & 2 & 2.13 & 35 & 67.3 \\
\hline & & TCT1.5 & Have sufficient content knowledge & $\begin{array}{l}\text { Transitional } \\
\text { Knowing }\end{array}$ & 7 & 7.45 & 8 & 15.3 \\
\hline & & TCT1.6 & Provide-prepare instructional tools & $\begin{array}{l}\text { Transitional } \\
\text { Knowing }\end{array}$ & 1 & 1.06 & 24 & 46.1 \\
\hline & & TCT1.7 & Use the language properly & $\begin{array}{l}\text { Transitional } \\
\text { Knowing }\end{array}$ & 2 & 2.13 & 3 & 5.77 \\
\hline & \multirow{9}{*}{ 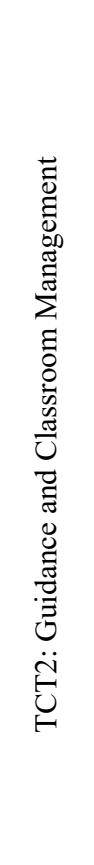 } & ТCT2.1 & Create a safe learning environment & $\begin{array}{l}\text { Transitional } \\
\text { Knowing }\end{array}$ & 2 & 2.13 & 4 & 7.69 \\
\hline & & TCT2.2 & Physically suit the classroom to teaching & $\begin{array}{l}\text { Transitional } \\
\text { Knowing }\end{array}$ & 13 & 13.8 & 18 & 34.6 \\
\hline & & TCT2.3 & $\begin{array}{l}\text { Be consistent and reliable in his/her } \\
\text { behaviors }\end{array}$ & $\begin{array}{l}\text { Transitional } \\
\text { Knowing }\end{array}$ & 5 & 5.32 & 5 & 9.61 \\
\hline & & ТCT2.4 & Establish dominance in the classroom & $\begin{array}{l}\text { Transitional } \\
\text { Knowing }\end{array}$ & 29 & 30.9 & 30 & 57.6 \\
\hline & & TCT2.5 & $\begin{array}{l}\text { Contribute to personality development of } \\
\text { students }\end{array}$ & $\begin{array}{l}\text { Transitional } \\
\text { Knowing }\end{array}$ & 3 & 3.19 & 28 & 53.8 \\
\hline & & ТCT2.6 & Recognize his/her students & $\begin{array}{l}\text { Transitional } \\
\text { Knowing }\end{array}$ & 5 & 5.32 & 32 & 61.5 \\
\hline & & ТCT2.7 & Come to the class timely & $\begin{array}{l}\text { Transitional } \\
\text { Knowing }\end{array}$ & 2 & 2.13 & 5 & 9.61 \\
\hline & & ТCT2.8 & Be fair to students & $\begin{array}{l}\text { Transitional } \\
\text { Knowing }\end{array}$ & 4 & 4.26 & 27 & 51.9 \\
\hline & & ТCT2.9 & Lead students & $\begin{array}{l}\text { Independent } \\
\text { Knowing }\end{array}$ & 2 & 2.13 & 30 & 57.6 \\
\hline
\end{tabular}




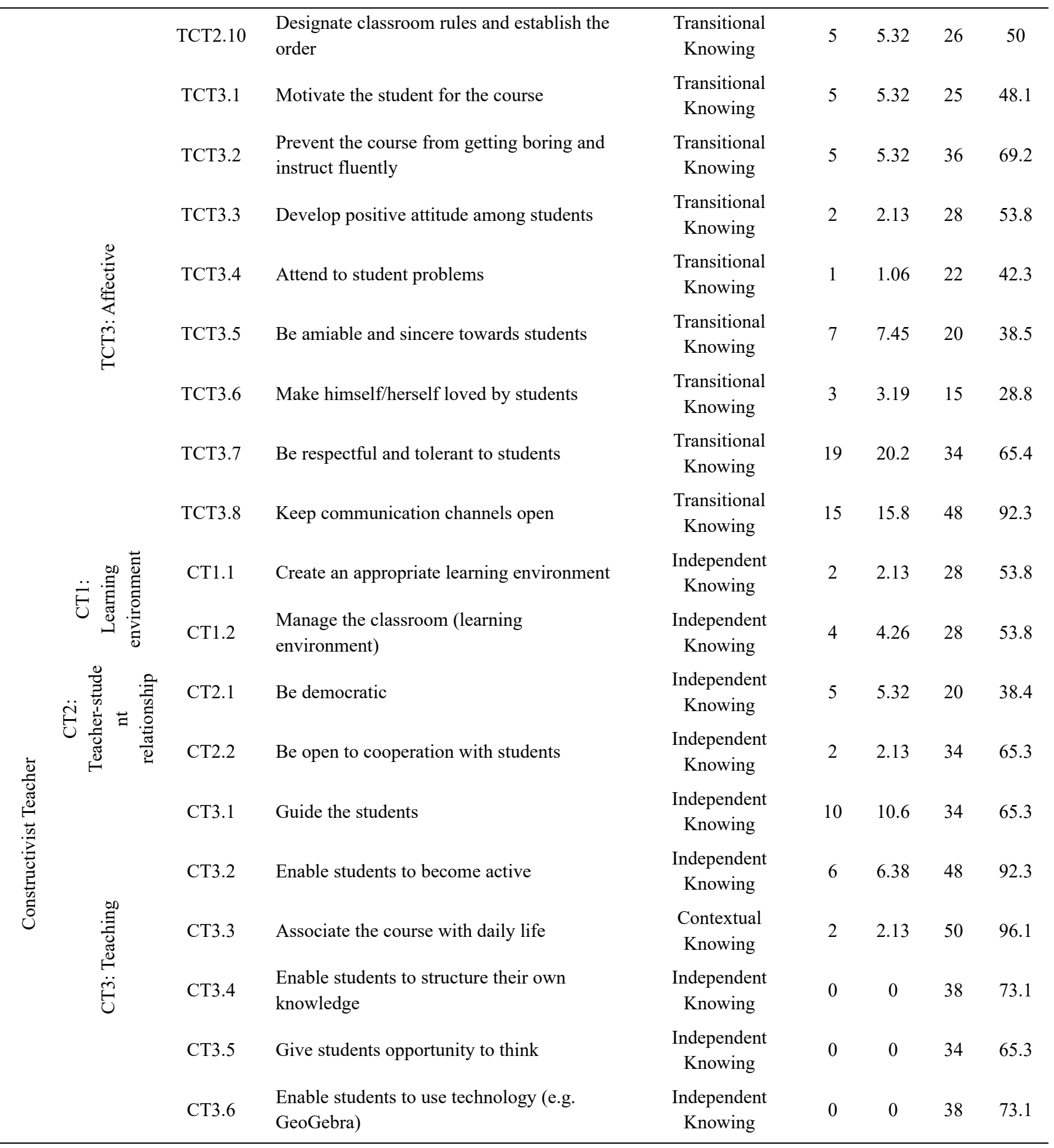

The following is the statement of PT45 who had had a traditional approach before the formation program in regard to the fact that teacher's role in the classroom setting is to establish authority or discipline, set example for students, relay and teach information, answer student questions, and be sympathetic (mother-father, older-younger sibling):

PT45 (Before Formation): Teachers should be authoritarian. They should be like a friend to students but also strike the balance between. ...teachers should set examples for students from all aspects. They should decide how they can relay information in the best way, instruct the subject in a way that students will understand it and answer questions to be asked by students. They should know well about the subject they will instruct, ...they should suit the classroom physically before instructing the course. And they should be disciplined...

PT45 changed his/her thoughts conforming with the traditional teacher approach regarding teacher roles in the 
classroom setting before the formation program with the ones conforming with the constructivist teacher approach after the program:

PT45 (After Formation): Teachers should not directly present a subject. They should prepare activities about the subject and have them performed in group works or individually. For example, they should not write down the formulation and say "memorize it" but enable students to explore where it the formulation comes from by means of activity. They should not teach with plain narration but also utilize instructional technologies when necessary. They should use concrete materials for explaining abstract concepts. By this means, the course will be more attention-grabbing and more retentive. They should provide students with proper feedbacks and enable them to deduce. Teachers should improve students' problem-solving skills. They should associate the subject with daily life in the introduction and attract student's attention. They should arouse students' curiosity about what they will learn.

Regarding the opinions in the theme of traditional and constructivist teacher, of the participants, $30.9 \%$ before the formation program and $57.6 \%$ after the program believed that teacher's role in the classroom is to establish dominance in the classroom; $20.2 \%$ before the program and $65.4 \%$ after the program believed that it is to be respectful and tolerant to students; $15.8 \%$ before the program and 92.3 after the program believed that it is to keep communication channels open; and $13.8 \%$ before the program and $34.6 \%$ after the program believed that it is physically suit the classroom to teaching.

It is observed that low rates of the codes concerning the theme of traditional and constructivist teacher before the formation program saw a significant increase after the program. It is seen that the preservice teachers believed that teacher's role is to ask students questions $(2.13 \%$ before the formation program, $15.3 \%$ after the program), to ensure student readiness $(1.06 \%$ before the program, $28.8 \%$ after the program), to provide reinforcers and feedbacks $(1.06 \%$ before the program, $76.9 \%$ after the program), to come to the class prepared $(2.13 \%$ before the program, $67.3 \%$ after the program), to have sufficient content knowledge ( $7.45 \%$ before the program, $15.3 \%$ after the program), and to provide-prepare instructional tools (1.06\% before the program, $46.1 \%$ after the program) in terms of field and teaching. In terms of guidance and classroom management, the preservice teachers believed that teacher's role in the classroom is to create a safe learning environment (2.13\% before the formation program, $7.69 \%$ after the program), to be consistent and reliable in his/her behaviors (5.32\% before the program, $9.61 \%$ after the program), to contribute to personality development of students $(3.19 \%$ before the program, $53.8 \%$ after the program), to recognize his/her students $(5.32 \%$ before the program, $61.5 \%$ after the program $)$, to come to the class timely $(2.13 \%$ before the program, $9.61 \%$ after the program), to be fair to students ( $4.26 \%$ before the program, $51.9 \%$ after the program), to lead the students $(2.13 \%$ before the program, $57.6 \%$ after the program), and to designate classroom rules and establish the order $(5.32 \%$ before the program, $50 \%$ after the program) while they believed that it is to motivate the student for the course $(5.32 \%$ before the program, $48.1 \%$ after the program), to prevent the course from getting boring and instruct fluently ( $4.32 \%$ before the program, $69.2 \%$ after the program), to develop positive attitudes among students ( 2.13 before the program, $53.8 \%$ after the program), to attend to student problems (1.06\% before the program, $42.3 \%$ after the program), to be amiable and sincere towards students $(7.45 \%$ before the program, $38.5 \%$ after the program), and to make himself/herself loved by students $(3.19 \%$ before the program, $28.8 \%$ after the program) from the affective perspective.

As for the opinions in the theme of constructivist teacher, these codes about teacher roles had been emphasized by very few of the preservice teachers before the formation program but a significant part of them emphasized these codes after the program. It is understood from these codes that the preservice teachers believed that teacher's role is to create an appropriate learning environment ( $2.13 \%$ before the formation program, $53.8 \%$ after the program), to manage the classroom (learning environment) $(4.26 \%$ before the program, $53.8 \%$ after the program) in terms of learning environment while they believed that it is to be democratic $(5.32 \%$ before the program, $38.4 \%$ after the program), to be open to cooperation with students $(2.13 \%$ before the program, $65.3 \%$ after the program in terms of teacher-student relationship); and that it is to guide the students (10.6\% before the program, $65.3 \%$ after the program), to enable students to become active $(6.38 \%$ before the program, $92.3 \%$ after the program), and to associate the course with daily life $(2.13 \%$ before the program, $96.1 \%$ after the program) in terms of teaching. Of the preservice teachers, $78.1 \%$ started to believe that teacher's role is to enable students to structure their own knowledge, $65.3 \%$ started to believe that it is to give students opportunity to think, and $73.1 \%$ started to believe that it is to enable them to use technology (e.g. GeoGebra) although none of them had expressed any of these teacher roles before the formation program.

For instance, PT30 who provided statements similar to those of PT45 above had mentioned before the formation 
program that teacher's role in the classroom setting is to establish authority or discipline, to relay and teach information and to designate classroom rules and establish order:

PT30 (Before Formation): ...to establish authority in the classroom, relay what they know to the student completely and guide them. In addition, it is also to designate classroom rules and ensure that students behave according to these rules.

PT30 also changed his/her thoughts conforming with the traditional teacher approach about teacher roles in the classroom setting before the formation program with the ones conforming with the constructivist teacher approach after the program:

PT30 (After Formation): Teacher's primary role is to guide the students. They should prepare an environment to activate students and act accordingly. That is to say, they should not offer the information directly but have the students find it through group works and guide them while finding it. It is to ensure what they have learned is more retentive. They should also keep communication channels open to manage the classroom. Teachers should establish dialogs with the students frequently and provide appropriate feedbacks during the course to help them find what is right. Teachers are also an authority in the classroom. Class order and dominance are up to them.

The percentage and frequency values of the codes achieved from the preservice mathematics teachers' statements on student roles in the classroom setting before and after the formation program are given in Table 3.

According to Table 3, the preservice teacher opinions on student roles in the classroom setting were grouped in three different themes of "Traditional Student" "Traditional and Constructivist Student", and "Constructivist Student".

Table 3. Distribution of Opinions on Student Roles

\begin{tabular}{|c|c|c|c|c|c|c|c|c|}
\hline \multirow[t]{2}{*}{$\stackrel{\mathscr{E}}{\stackrel{\Xi}{\Xi}}$} & \multirow{2}{*}{ 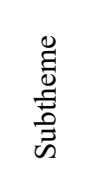 } & & \multirow[t]{2}{*}{ Codes } & \multirow{2}{*}{$\begin{array}{l}\text { Levels of Baxter } \\
\text { Magolda's (1992) } \\
\text { Epistemological } \\
\text { Reflection Model }\end{array}$} & \multicolumn{2}{|c|}{$\begin{array}{c}\text { Before } \\
\text { Formation } \\
\text { Program }\end{array}$} & \multicolumn{2}{|c|}{$\begin{array}{c}\text { After } \\
\text { Formation } \\
\text { Program }\end{array}$} \\
\hline & & & & & $\mathrm{f}$ & $\%$ & $\mathrm{f}$ & $\%$ \\
\hline \multirow{6}{*}{ 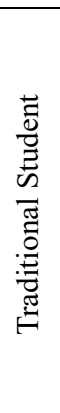 } & \multirow{3}{*}{ 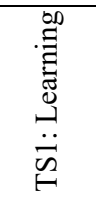 } & TS1.1 & Listen to the teacher carefully and silently & Absolute & 40 & 42.6 & 5 & 9.62 \\
\hline & & TS1.2 & Rehearse and learn what has been told & Absolute & 36 & 38.3 & 1 & 1.92 \\
\hline & & TS1.3 & $\begin{array}{l}\text { Write what has been told down on the } \\
\text { notebook properly }\end{array}$ & Absolute & 3 & 3.19 & 1 & 1.92 \\
\hline & \multirow{3}{*}{ 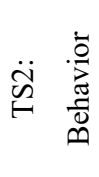 } & $\mathrm{TS} 2.1$ & Be careful about his/her appearance & Absolute & 2 & 2.13 & 0 & 0 \\
\hline & & TS2.2 & Take the teacher as an example/model & Absolute & 1 & 1.06 & 0 & 0 \\
\hline & & TS2.3 & Abide the authority & Absolute & 2 & 2.13 & 0 & 0 \\
\hline \multirow{8}{*}{ 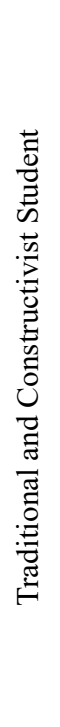 } & \multirow{4}{*}{ 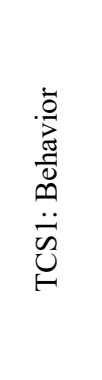 } & TCS1.1 & Know his/her duties and responsibilities & $\begin{array}{l}\text { Transitional } \\
\text { Knowing }\end{array}$ & 23 & 24.5 & 30 & 57.6 \\
\hline & & TCS1.2 & Follow classroom rules & $\begin{array}{l}\text { Transitional } \\
\text { Knowing }\end{array}$ & 30 & 31.1 & 27 & 51.9 \\
\hline & & TCS1.3 & Ask for permission to speak in the course & $\begin{array}{l}\text { Transitional } \\
\text { Knowing }\end{array}$ & 7 & 7.45 & 2 & 3.8 \\
\hline & & TCS1.4 & Not to be absent from school & $\begin{array}{l}\text { Transitional } \\
\text { Knowing }\end{array}$ & 1 & 1.06 & 0 & 0 \\
\hline & \multirow{4}{*}{ 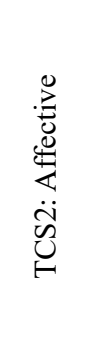 } & TCS2.1 & Have a good communication with the teacher & $\begin{array}{l}\text { Transitional } \\
\text { Knowing }\end{array}$ & 2 & 2.13 & 15 & 28.8 \\
\hline & & TCS2.2 & Be respectful towards the teacher-friends & $\begin{array}{l}\text { Transitional } \\
\text { Knowing }\end{array}$ & 48 & 51.1 & 16 & 30.7 \\
\hline & & TCS2.3 & $\begin{array}{l}\text { Be respectful towards himself/herself and } \\
\text { have morals }\end{array}$ & $\begin{array}{l}\text { Transitional } \\
\text { Knowing }\end{array}$ & 3 & 3.19 & 0 & 0 \\
\hline & & TCS2.4 & Be avid and have positive attitudes towards & Transitional & 12 & 12.8 & 20 & 38.4 \\
\hline
\end{tabular}




\begin{tabular}{|c|c|c|c|c|c|c|c|c|}
\hline & & & the course & Knowing & & & & \\
\hline & & TCS3.1 & Make effort to learn & $\begin{array}{l}\text { Transitional } \\
\text { Knowing }\end{array}$ & 25 & 26.6 & 18 & 34.6 \\
\hline & & TCS3.2 & Come to the class prepared and timely & $\begin{array}{c}\text { Transitional } \\
\text { Knowing }\end{array}$ & 4 & 4.26 & 14 & 26.9 \\
\hline & $\stackrel{\infty}{\Xi}$ & TCS3.3 & Keep course materials prepared & $\begin{array}{l}\text { Transitional } \\
\text { Knowing }\end{array}$ & 1 & 1.06 & 24 & 46.2 \\
\hline & $\stackrel{\vec{J}}{\stackrel{\Xi}{\oplus}}$ & TCS3.4 & Have new information and ideas & $\begin{array}{l}\text { Transitional } \\
\text { Knowing }\end{array}$ & 1 & 1.06 & 4 & 7.69 \\
\hline & $\sum_{0}^{\infty}$ & TCS3.5 & Have readiness (preliminary learning) & $\begin{array}{l}\text { Transitional } \\
\text { Knowing }\end{array}$ & 13 & 13.8 & 29 & 55.7 \\
\hline & & TCS3.6 & Ask and answer questions & $\begin{array}{c}\text { Transitional } \\
\text { Knowing }\end{array}$ & 14 & 14.9 & 25 & 48.1 \\
\hline & & TCS3.7 & $\begin{array}{l}\text { Solve questions to reinforce what he/she has } \\
\text { learned }\end{array}$ & $\begin{array}{c}\text { Transitional } \\
\text { Knowing }\end{array}$ & 0 & 0 & 14 & 26.9 \\
\hline & & CS1.1 & Be active and avid in the course & $\begin{array}{l}\text { Independent } \\
\text { Knowing }\end{array}$ & 13 & 13.8 & 39 & 75 \\
\hline$\stackrel{\overrightarrow{0}}{\frac{\tilde{D}}{E}}$ & $\stackrel{\infty}{\Xi}$ & $\mathrm{CS} 1.2$ & Study in cooperation with his/her friends & $\begin{array}{l}\text { Independent } \\
\text { Knowing }\end{array}$ & 1 & 1.06 & 29 & 55.8 \\
\hline 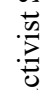 & 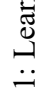 & CS1.3 & Accept teacher's guidance & $\begin{array}{l}\text { Independent } \\
\text { Knowing }\end{array}$ & 1 & 1.06 & 22 & 42.3 \\
\hline 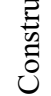 & $\tilde{U}$ & CS1.4 & Think, question, discuss and judge & $\begin{array}{l}\text { Contextual } \\
\text { Knowing }\end{array}$ & 1 & 1.06 & 28 & 53.8 \\
\hline & & CS1.5 & Explore and structure information & $\begin{array}{l}\text { Independent } \\
\text { Knowing }\end{array}$ & 0 & 0 & 37 & 71.2 \\
\hline
\end{tabular}

While the codes in the theme of traditional student had been emphasized at a high rate by the preservice teachers before the formation program, this rate was observed to decrease after the program. It is understood from these codes that the preservice teachers believed that student's role is to listen to the teacher carefully and silently ( $42.6 \%$ before the formation program, $9.62 \%$ after the program), to rehearse and learn what has been told $(38.3 \%$ before the program, $1.92 \%$ after the program), and to write what has been told down on the notebook properly (3.19\% before the program, $1.92 \%$ after the program) in terms of learning. Despite being at a lower rate, some of the preservice teachers had believed that student's role is to be careful about his/her appearance $(2.13 \%)$, to take the teacher as an example/model $(1.06 \%)$, and to abide the authority $(2.13 \%)$ before the formation program. It is seen that the preservice teachers changed their thoughts concerning these codes after the formation program.

For example, the following is the statement of PT15 who had had a traditional approach before the program about student roles in the classroom setting which are to listen to the teacher carefully and silently and to rehearse and learn what has been told:

PT15 (Before Formation): Student's single role in the classroom is to listen to the teacher silently and learn what has been told. Students should make effort to learn in whatever way, either by memorizing, listening or reading.

PT15 changed his/her thoughts conforming with the traditional student approach about student roles in the classroom setting before the formation program with ones conforming with the constructivist student approach after the program:

PT15 (After Formation): ...student should be in the central position in the classroom. Students should join activities actively under the guidance of teacher. They take teacher guidance into account in achieving information. They should be able to question and present their ideas freely and not refrain from suggesting new ideas.

It is observed that low rates of the codes in the theme of traditional and constructivist student before the formation 
program saw a significant increase after the program. It is understood from these codes that the preservice teachers believed that student's role is to know his/her duties and responsibilities $(24.5 \%$ before the formation program, $57.6 \%$ after the program) and to follow classroom rules (31.1\% before the program, $51.9 \%$ after the program) in terms of behavior; it is to have a good communication with the teacher ( $2.13 \%$ before the program, $28.89 \%$ after the program) and to be avid and have positive attitudes towards the course (12.8\% before the program, $38.4 \%$ after the program) from the affective perspective; in terms of learning, they believed that it is to make effort to learn $(26.6 \%$ before the program, after the program), to come to the class prepared and timely $(4.26 \%$ before the program, $26.9 \%$ after the program), to keep course materials prepared (1.06\% before the program, $46.2 \%$ after the program), to have new information and ideas (1.06\% before the program, $7.69 \%$ after the program), to have readiness (preliminary learning) (13.8\% before the program, $55.7 \%$ after the program), and to ask and answer questions ( $14.9 \%$ before the formation, $48.1 \%$ after the formation).

Whereas the codes in the theme of constructivist student had been emphasized by very few of the preservice teachers before the formation program, a significant part of the preservice teachers emphasized them after the program. It is understood from these codes that the preservice teachers believed that student's role is to be active and avid in the course $(13 \%$ before the program, $75 \%$ after the program), to study in cooperation with his/her friends $(1.06 \%$ before the program, $55.8 \%$ after the program), to accept teacher guidance $(1.06 \%$ before the program, $42.3 \%$ after the program), and to think, question, discuss and judge (1.06\% before the program, $53.8 \%$ after the program). Although none of the preservice teachers had expressed it before the formation program, $71.2 \%$ of them developed the belief that student's role is to explore and structure information after the program.

Similarly, to the case of PT15, PT43 stated before the formation program that student's role in the classroom setting is to listen to the teacher carefully and silently, to write what has been told down on the notebook properly, to ask and answer question, to be respectful towards the teacher-friends, and to follow classroom rules:

PT43 (Before Formation): It is that students listen to the teacher very carefully and focus on the course when the teacher starts the course. They should note down what is told properly, participate in the course and answer the question or provide opinion when the teacher writes down an example. They should not exceed the limits of respect even when answering or solving the question. They should act according to the classroom rules.

PT43 also changed his/her thoughts conforming with the traditional student approach about student roles in the classroom setting before the formation program with ones conforming with the constructivist student approach after the program. Here is PT43's own statement:

PT43 (After Formation): Student should be the most active person in the classroom. He/she should question a new situation, look into and ponder it. He/she participate in the activities actively under the guidance of teacher to achieve the information by himself/herself.

The codes that were achieved from the opinions provided by the preservice teachers were associated with the drawings made by them before and after the formation program about teacher and student roles, and they are presented in Table 4 and Table 5.

Considering the drawings made in regard to teacher roles before the program (see Table 4), the drawings were associated with some of the codes in the themes of traditional teacher, traditional and constructivist teacher, and constructivist teacher at a lower rate while they were associated with some of the codes at a significant rate. As for the codes associated at a higher rate, $74.46 \%$ of the drawings made by the participants were about relaying and teaching information, which were classified in the theme of traditional teacher, and 37.23\% were about asking students questions, which were classified in the theme of traditional and constructivist teacher. On the other hand, concerning the drawings made in regard to teacher roles after the program (see Table 5), most of the drawings were about the codes classified in the themes of traditional and constructivist teacher and constructivist teacher. 


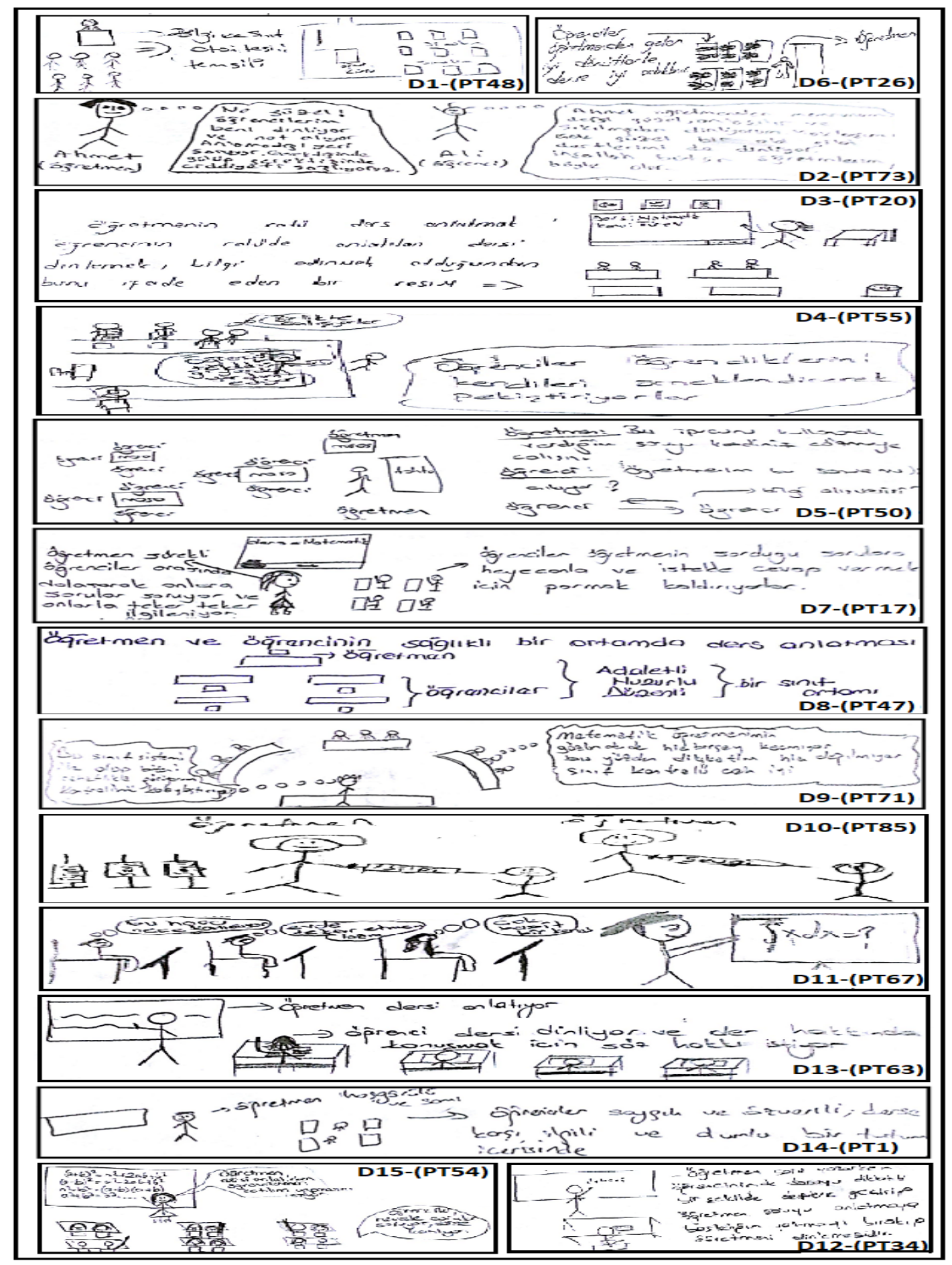

Figure 1. Drawings Made about Teacher and Student Roles before the Formation Program 
Table 4. Association of the Drawings Made about Teacher and Student Roles and the Codes Achieved from the Preservice Teacher Statements before the Formation Program

\begin{tabular}{|c|c|c|c|c|c|c|c|c|c|c|c|c|c|c|c|c|c|}
\hline & & \multicolumn{14}{|c|}{ Drawings } & \multirow[b]{2}{*}{$\mathrm{f}$} & \multirow[b]{2}{*}{$\%$} \\
\hline \multicolumn{2}{|c|}{$\begin{array}{c}\text { Codes Concerning } \\
\text { Teacher Roles }\end{array}$} & $\Xi$ & $\underset{N}{\nabla}$ & $\underset{\omega}{\Xi}$ & $\underset{\perp}{\ominus}$ & $\underset{\cup}{\ominus}$ & $\nabla$ & $\Xi$ & $\nabla_{\infty}$ & $\oslash_{\sigma}$ & $\underset{\sigma}{\ominus}$ & $\underset{\Xi}{\Xi}$ & $\frac{\Xi}{N}$ & $\underset{\omega}{\Xi} \underset{\perp}{\Omega}$ & $\underset{v}{\stackrel{\ominus}{u}}$ & & \\
\hline \multirow{3}{*}{ ヒ } & TT1.1 & & $*$ & & & & & & & & & & & & & 1 & 1.06 \\
\hline & TT1.2 & * & & & & & & & & & & & & & & 7 & 7.45 \\
\hline & TT2.1 & & & $*$ & & & & & & & & & & & & 70 & 74.46 \\
\hline \multirow{8}{*}{$\underset{ヒ}{\bullet}$} & TCT1.1 & & $*$ & & $*$ & $*$ & & $*$ & & & & & & & & 35 & 37.23 \\
\hline & TCT1.3 & & & & & & $*$ & & & & & & & & & 3 & 3.19 \\
\hline & TCT2.4 & & & & & & & & & $*$ & & & & & & 2 & 2.13 \\
\hline & TCT2.8 & & & & & & & & $*$ & & & & & & & 1 & 1.06 \\
\hline & TCT3.5 & & & & & & & & & & $*$ & & & & & 3 & 3.19 \\
\hline & ТCT3.6 & & & & & & & & & & $*$ & & & & & 3 & 3.19 \\
\hline & ТCT3.7 & & & & $*$ & & & & $*$ & & & & & & & 4 & 4.26 \\
\hline & ТCT3.8 & & & & $*$ & & & & & & & & & & & 4 & 4.26 \\
\hline \multirow{3}{*}{ 战 } & CT2.1 & & & & $*$ & * & & & & & & & & & & 4 & 4.26 \\
\hline & CT2.2 & & & & $*$ & * & & & & & & & & & & 4 & 4.26 \\
\hline & CT2.3 & & & & $*$ & $*$ & & & & & & & & & & 4 & 4.26 \\
\hline \multicolumn{18}{|c|}{ Codes Concerning } \\
\hline \multicolumn{2}{|c|}{ Student Roles } & & & & & & & & & & & & & & & $\mathrm{f}$ & $\%$ \\
\hline \multirow{3}{*}{$\mathscr{H}$} & TS1.1 & & & & & & $*$ & & & $*$ & & & & & & 71 & 75.53 \\
\hline & TS1.2 & & & & & & & & & & & $*$ & & & & 2 & 2.13 \\
\hline & TS1.3 & & $*$ & & & & & & & & & $*$ & $*$ & & & 17 & 18.08 \\
\hline \multirow{4}{*}{$\bigcup_{\theta}^{\infty}$} & TCS1.3 & & & & & & & & & & & & & $*$ & & 3 & 3.19 \\
\hline & TCS2.2 & & & & & & & & & & & & & $*$ & & 3 & 3.19 \\
\hline & TCS2.4 & & & & $*$ & & & & & & & & & * & $*$ & 5 & 5.32 \\
\hline & TCS3.6 & & & & $*$ & $*$ & & & & & & & $*$ & & $*$ & 39 & 41.49 \\
\hline$\tilde{U}$ & CS1.1 & & & & $*$ & $*$ & & & & & & & & & & 6 & 6.38 \\
\hline
\end{tabular}

Given the drawings made in regard to student roles before the program (see Figure 2 and Table 4), the drawings were associated with some of the codes in the themes of traditional student, traditional and constructivist student, and constructivist student at a lower rate while they were associated with some of the codes at a significant rate. As for the codes associated at a higher rate, the drawings made by the participants were about listening to the teacher carefully and silently (75.53\%), writing down what has been told down on the notebook properly (18.08\%), which were classified in the theme of traditional student, and about asking and answering questions (41.49\%), which was classified in the theme of traditional and constructivist student. However, concerning the drawings made in regard to student roles after the program (see Figure 3 and Table 5), most of the drawings were about the codes classified in the themes of traditional and constructivist student and constructivist student. 


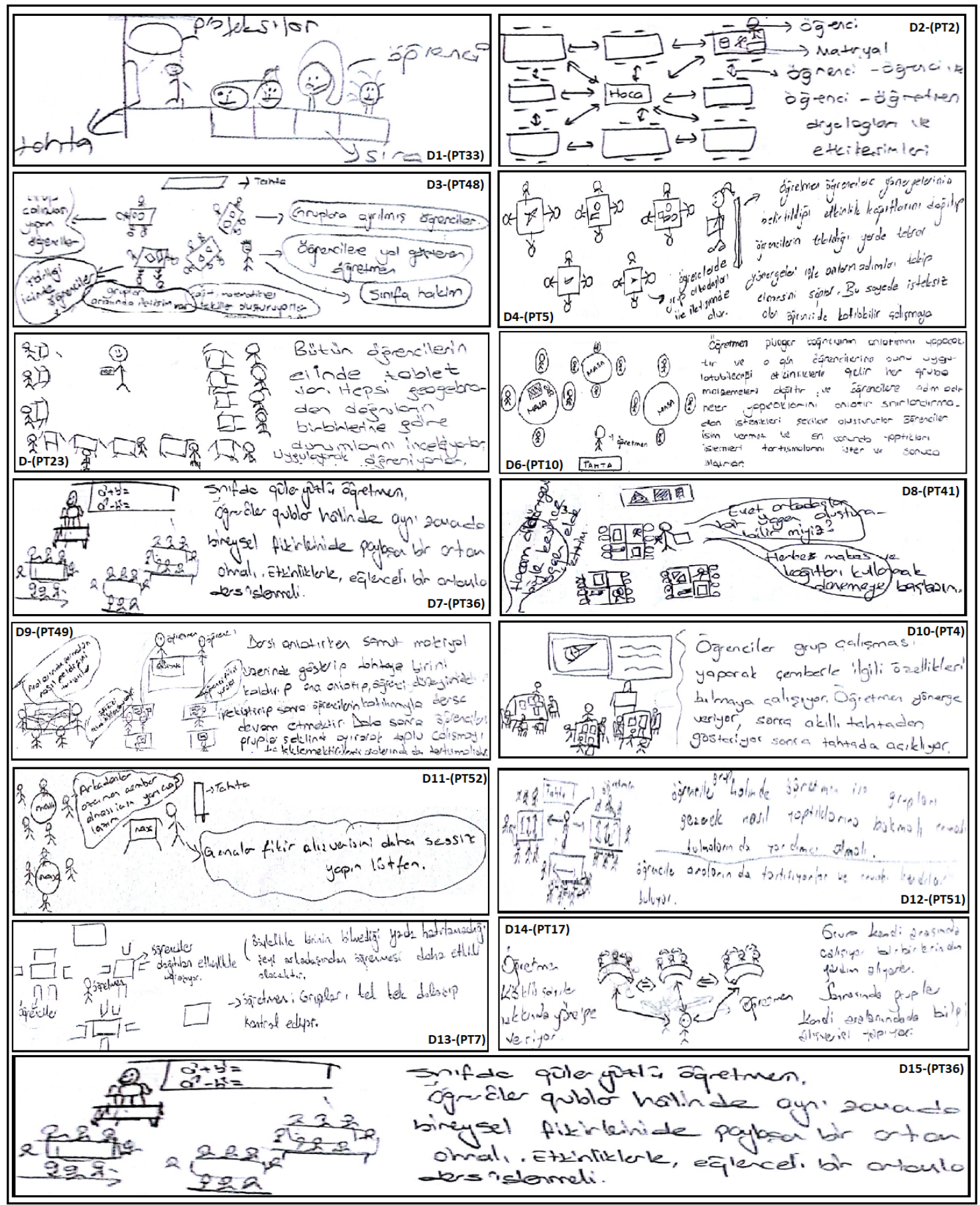

Figure 2. Drawings Made about Teacher and Student Roles after the Formation Program 
Table 5. Association of the Drawings Made about Teacher and Student Roles and the Codes Achieved from the Preservice Teacher Statements after the Formation Program

\begin{tabular}{|c|c|c|c|c|c|c|c|c|c|c|c|c|c|c|c|c|c|c|c|}
\hline \multirow{2}{*}{\multicolumn{2}{|c|}{$\begin{array}{l}\text { Codes Concerning } \\
\text { Teacher Roles }\end{array}$}} & \multicolumn{16}{|c|}{ Drawings } & \multirow[b]{2}{*}{$\mathrm{f}$} & \multirow[b]{2}{*}{$\%$} \\
\hline & & $\bigoplus$ & $\nabla_{N}$ & $\oslash_{\omega}$ & $\bigoplus_{\perp}$ & $\underset{u}{\ominus}$ & 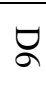 & 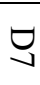 & $\varpi_{\infty}$ & ఠ̧ & 5 & & $\underset{\Xi}{\Xi}$ & $\underset{N}{\Xi}$ & $\underset{\omega}{\Xi}$ & $\stackrel{\Omega}{D}$ & $\underset{\sim}{\ominus}$ & & \\
\hline 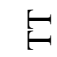 & TT2.1 & $*$ & & & & & & & & & & & & & & & & 1 & 1.92 \\
\hline \multirow{9}{*}{ U } & TCT1.1 & & & $*$ & & & & & & & & & & & & & & 9 & 17.3 \\
\hline & TCT1.3 & & & $*$ & $*$ & * & $*$ & $*$ & * & 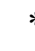 & & * & $*$ & $*$ & $*$ & * & $*$ & 40 & 76.9 \\
\hline & TCT1.4 & & $*$ & * & $*$ & * & $*$ & $*$ & * & 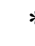 & & * & $*$ & $*$ & $*$ & * & $*$ & 51 & 98.1 \\
\hline & TCT1.6 & & $*$ & * & $*$ & * & $*$ & $*$ & $*$ & 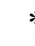 & & * & $*$ & $*$ & $*$ & * & $*$ & 51 & 98.1 \\
\hline & ТСТ2.4 & $*$ & $*$ & $*$ & $*$ & * & $*$ & $*$ & * & 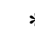 & & * & $*$ & $*$ & $*$ & $*$ & $*$ & 52 & 100 \\
\hline & ТСТ2.8 & & $*$ & $*$ & $*$ & * & $*$ & $*$ & * & 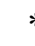 & & * & $*$ & $*$ & $*$ & $*$ & $*$ & 51 & 98.1 \\
\hline & ТСТ3.2 & & $*$ & $*$ & $*$ & * & $*$ & $*$ & * & 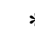 & & * & $*$ & $*$ & $*$ & $*$ & $*$ & 51 & 98.1 \\
\hline & ТСТ3.5 & & $*$ & $*$ & & & & & & & & & & & & & $*$ & 20 & 3.5 \\
\hline & ТСТ3.8 & & $*$ & * & $*$ & * & $*$ & $*$ & $*$ & " & & * & $*$ & $*$ & $*$ & * & $*$ & 51 & 98.1 \\
\hline \multirow{9}{*}{ 仙 } & CT1.1 & & $*$ & $*$ & $*$ & * & $*$ & $*$ & $*$ & 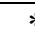 & & * & $*$ & $*$ & $*$ & * & $*$ & 51 & 98.1 \\
\hline & CT1.2 & & & $*$ & $*$ & * & $*$ & $*$ & $*$ & 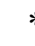 & & * & $*$ & $*$ & $*$ & $*$ & $*$ & 51 & 98.1 \\
\hline & CT2.1 & & & $*$ & $*$ & * & $*$ & $*$ & * & " & & * & $*$ & * & $*$ & * & $*$ & 51 & 98.1 \\
\hline & CT2.2 & & & $*$ & $*$ & * & $*$ & $*$ & * & " & & * & $*$ & * & $*$ & * & $*$ & 51 & 98.1 \\
\hline & СТ3.1 & & & $*$ & * & * & $*$ & $*$ & * & 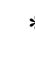 & & * & $*$ & $*$ & $*$ & * & $*$ & 51 & 98.1 \\
\hline & CT3.2 & & $*$ & $*$ & * & * & $*$ & $*$ & * & 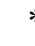 & & * & $*$ & $*$ & $*$ & * & $*$ & 51 & 98.1 \\
\hline & CT3.4 & & $*$ & $*$ & * & * & * & $*$ & * & 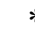 & & * & $*$ & $*$ & $*$ & * & $*$ & 51 & 98.1 \\
\hline & CT3.5 & & $*$ & $*$ & * & * & $*$ & $*$ & * & " & & * & $*$ & $*$ & $*$ & $*$ & $*$ & 51 & 98.1 \\
\hline & СT3.6 & $*$ & $*$ & & & * & & & & & & * & & & & & & 40 & 76.9 \\
\hline \multicolumn{2}{|c|}{$\begin{array}{l}\text { Codes Concerning } \\
\text { Student Roles }\end{array}$} & & & & & & & & & & & & & & & & & $\mathrm{f}$ & $\%$ \\
\hline $\mathscr{\omega}$ & TS1.1 & $*$ & & & & & & & & & & & & & & & & 1 & 1.92 \\
\hline \multirow{2}{*}{$\bigcup_{H}^{\infty}$} & TCS2.1 & & $*$ & $*$ & $*$ & * & $*$ & $*$ & * & 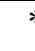 & & * & $*$ & $*$ & $*$ & * & $*$ & 51 & 98.1 \\
\hline & TCS3.6 & & $*$ & * & $*$ & * & $*$ & $*$ & * & 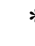 & & * & $*$ & $*$ & $*$ & $*$ & $*$ & 51 & 98.1 \\
\hline \multirow{5}{*}{$\tilde{U}$} & CS1.1 & & $*$ & * & $*$ & * & $*$ & $*$ & $*$ & 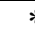 & & * & $*$ & $*$ & $*$ & * & $*$ & 51 & 98.1 \\
\hline & CS1.2 & & $*$ & $*$ & $*$ & * & $*$ & $*$ & * & " & & * & $*$ & $*$ & $*$ & * & $*$ & 51 & 98.1 \\
\hline & CS1.3 & & $*$ & $*$ & $*$ & * & $*$ & $*$ & * & " & & * & $*$ & $*$ & $*$ & $*$ & $*$ & 51 & 98.1 \\
\hline & CS1.4 & & $*$ & $*$ & $*$ & $*$ & $*$ & $*$ & $*$ & 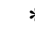 & & * & $*$ & $*$ & $*$ & $*$ & $*$ & 51 & 98.1 \\
\hline & CS1.5 & & & $*$ & $*$ & * & $*$ & $*$ & * & 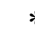 & & * & $*$ & $*$ & $*$ & $*$ & $*$ & 51 & 98.1 \\
\hline
\end{tabular}

Since some of the codes concerning teacher and student roles were expressed at the beginning of the formation program, some of them at the end of the program and a significant part of them both at the beginning and end of the program, as seen in Table 2 and Table 3, the codes expressed by $10 \%$ or above were taken into account to decide the change in the preservice teachers' beliefs about teacher and student roles and their numbers in the levels of Baxter Magolda's (1992) Epistemological Reflection Model were determined (Table 6 and Table 7). 
Table 6. Number of Emphasized Codes According to Epistemological Reflection Model Levels in terms of Teacher Roles

\begin{tabular}{|c|c|c|c|c|}
\hline \multirow{3}{*}{ Belief } & \multicolumn{4}{|c|}{ Belief Levels } \\
\hline & $\begin{array}{l}\text { Absolute } \\
\text { Knowing }\end{array}$ & $\begin{array}{c}\text { Transitional } \\
\text { Knowing }\end{array}$ & $\begin{array}{c}\text { Independent } \\
\text { Knowing }\end{array}$ & $\begin{array}{c}\text { Contextual } \\
\text { Knowing }\end{array}$ \\
\hline & \multicolumn{4}{|c|}{ Number of emphasized codes according to the levels } \\
\hline Before Formation Program & 3 & 4 & 1 & 0 \\
\hline After Formation Program & 0 & 19 & 11 & 1 \\
\hline
\end{tabular}

According to Table 6, of the codes achieved from the preservice teacher opinions on teacher roles before the formation program, 3 were about absolute, 4 were about transitional, and 1 was about independent knowing. On the other hand, of the codes achieved from the opinions after the formation program, 19 were about transitional and 11 were about independent knowing level. As also seen in Table 2, since the numbers of codes given in Table 6 refer to the codes expressed by the preservice teachers by $10 \%$ and above, it is observed that the preservice teachers had emphasized perceptions on the levels of absolute and transitional knowing before the formation program whereas they highlighted perceptions on the levels of transitional and independent knowing after the program in terms of teacher roles. As for the drawings made by the preservice teachers before the formation program, a significant part of the preservice teachers, which was $74.46 \%$, made drawings about the teacher role of relaying and teaching information, which reflected the level of absolute knowing, while $37.23 \%$ of them made drawings about the teacher role of asking students questions, which reflected the level of transitional knowing. Given the drawings made after the formation program, majority of the preservice teachers made drawings which were consistent with the levels of transitional and independent knowing and reflected the constructivist teacher approach. To address these data as a whole, the preservice teachers had had beliefs placed somewhere between absolute and transitional knowing before the formation program, and it turned out after the program that they had beliefs placed somewhere between transitional and independent knowing in terms of teacher roles.

Table 7. Number of Emphasized Codes According to Epistemological Reflection Model levels in terms of Student Roles

\begin{tabular}{ccccc}
\hline & \multicolumn{4}{c}{ Belief Levels } \\
\cline { 2 - 5 } Belief & Absolute & Transitional & Independent \\
& Knowing & Knowing & Knowing & Contextual \\
& & & Number of emphasized codes according to the levels \\
\cline { 2 - 5 } & 2 & 5 & 1 & 0 \\
\hline Before Formation Program & 0 & 11 & 4 & 0 \\
After Formation Program & & & 4 & \\
\hline
\end{tabular}

According to Table 7, of the codes achieved from the preservice teacher opinions on student roles before the formation program, 2 were about absolute, 5 were about transitional, and 1 was about independent knowing. On the other hand, of the codes achieved from the opinions after the formation program, 11 were about transitional and 4 were about independent knowing level. As also seen in Table 3, since the numbers of codes given in Table 7 refer to the codes expressed by the preservice teachers by $10 \%$ and above, it is observed that the preservice teachers emphasized perceptions on the levels of absolute and transitional knowing before the formation program whereas they highlighted perceptions on the levels of transitional and independent knowing after the program in terms of student roles. Concerning the drawings made by the preservice teachers before the formation program, a significant part of the preservice teachers, which was $75.53 \%$, made drawings about the student role of listening to the teacher carefully and silently, which reflected the level of absolute knowing, whereas $41.49 \%$ of them made drawings about the student role of asking and answering questions, which reflected the level of transitional knowing. As for the drawings made after the formation program, $98.1 \%$ of the preservice teachers made drawings which were consistent with the levels of transitional and independent knowing and reflected the constructivist student approach. Considering these data as a whole, the preservice teachers had had beliefs placed somewhere between absolute and 
transitional knowing before the formation program, and it turned out after the program that they had beliefs placed somewhere between transitional and independent knowing in terms of student roles.

\section{Discussion and Conclusion}

According to the findings on teacher roles, it was found that the preservice teachers had had beliefs and thoughts conforming with the traditional teacher approach mainly before the formation program. Before the formation program, the preservice teachers had believed that teacher's role in the classroom is to establish authority or discipline, to set examples for students, and to relay information to help students learn. The fact that the preservice teachers had had beliefs conforming the traditional teacher approach also reflected on their drawings about teacher roles before the preservice formation. A significant part of the drawings made by the preservice teachers was about the teacher role of relaying and teaching information. This result achieved before the formation program coincides with the results of the study performed by Köğce, Yıldız and Aydın (2010) on first-grade students of elementary mathematics teaching department. Köğce, Yıldız and Aydın (2010) observed that majority of the preservice teachers had opinions conforming to the traditional teacher approach (establishing the authority or order and relaying and teaching information) in regard to teacher roles in the classroom setting.

It is seen that the preservice teachers substantially changed the beliefs and thoughts conforming with the traditional teacher approach about teacher roles which they had had before the formation program with the constructivist teacher approach. After the formation program, according to the preservice teachers, teacher roles in the classroom are to create and manage an appropriate learning environment in which students will be active, to be open to cooperation with students, to guide the students, to associate subjects with daily life, to give the students opportunity to structure their own knowledge, to give students opportunity to think and explain their thoughts, and to enable them to use technology. The drawings made by the preservice teachers about teacher roles after the formation program reflect this result as well. It is observed that the drawings about teacher roles made after the program were substantially about codes in the themes of traditional and constructivist teacher and constructivist teacher. To examine the preservice teacher statements about teacher roles by association with Baxter Magolda's (1992) Epistemological Reflection Model, whereas the preservice teachers had had beliefs placed somewhere between absolute and transitional knowing levels about teacher roles before the formation program, they changed these beliefs with beliefs placed somewhere between transitional and independent knowing levels.

As for the findings on student roles, it was found that the preservice teachers mainly had had beliefs conforming with the traditional student approach and the traditional and constructivist student approach before the formation program. The preservice teachers had believed before the formation program that student's role in the classroom is to listen to the teacher carefully and silently, to rehearse and learn what has been told, to know his/her duties and responsibilities, to follow classroom rules, to be respectful towards the teacher and friends, to make effort to learn, to be avid towards the course, and to ask and answer questions. The fact that the preservice teachers had had beliefs conforming with the traditional student approach also reflected on their drawings about student roles before the preservice formation. A great part of the drawings made by the preservice teachers were about listening to the teacher carefully and silently and writing what has been told down on the notebook properly. It is understood that the preservice teachers substantially changed the beliefs and thoughts conforming with the traditional student approach about teacher roles which they had had before the formation program with the constructivist student approach. After the formation program, according to the preservice teachers, student's role in the classroom is to be active and avid in the course, to study in cooperation with his/her peers, to accept teacher's guidance, to think, question, discuss and judge, and to explore and structure information. The drawings made by the preservice teachers about student roles after the formation program reflect this result as well. It is observed that the drawings about student roles made after the program were substantially about codes in the themes of traditional and constructivist student and constructivist student. To address the preservice teacher statements about student roles by association with Baxter Magolda's (1992) Epistemological Reflection Model, whereas the preservice teachers had had beliefs placed somewhere between absolute and transitional knowing levels about student roles before the formation program, it was seen that they changed these beliefs with beliefs placed somewhere between transitional and independent knowing levels.

It can be concluded from these results regarding both teacher and student roles that the preservice teachers changed their beliefs conforming with the traditional approach before the formation program with the constructivist approach after the program. Tsai (2002) reported that school experiences of preservice teachers, their teaching practices and other instructional activities during their undergraduate education can influence their teaching-related beliefs. Thus, the reason why the preservice teachers had had beliefs conforming with the traditional approach about teacher and 
student roles before the formation program might be that they had received education mainly in traditional classroom settings where the teacher was more active and students were more passive in previous educational stages. In other words, the preservice teachers' experiences about learning and teaching in previous educational stages might have caused them to develop such a belief system. It can be argued that the preservice teachers changed their beliefs and thoughts conforming with the traditional approach about teacher and student roles before the formation program with the beliefs conforming to the constructivist approach after the program due to the influential experiences they had during the program. This indicated once again the importance of the pedagogic formation education performed in faculties of education to provide preservice teachers with general educational knowledge, content knowledge and curriculum knowledge. Hence, performance of teaching in accordance with curricular objectives depends on training preservice teachers so that they can acquire professional competences and values in line with the philosophical approaches of curriculum (Tunca, 2012) and beliefs.

\section{References}

Akpınar, B. (2010). The role of teachers, students and parents in constructivist approach. Education Overview, 6(16), $16-20$.

Arslan, M. M., \& Eraslan L. (2003). New education paradigm and the need for transformation in the Turkish education system. Journal of National Education, 160.

Aydın, M. (2010). Examining changes in mathematics teachers? Beliefs towards mathematics education (Unpublished Phd Dissertation). Karadeniz Technical University, Trabzon, Türkiye.

Bahçeci, B., Yıldırım, I., Kara, K., \& Keskinpalta, D. (2015). A Comparative study on the attitudes of students from education faculties and science faculties towards being A teacher. Journal of Erzincan University Faculty of Education, 17(1), 307-324.

Bakır, S., \& Adak, F. (2014). Epistemological beliefs of pre-service science teachers. Cumhuriyet International Journal of Education, 3(4), 24-36.

Baki, A. (2008). Mathematics education from theory to practice. Letter Education Publishing: Ankara.

Ball, D. (1998). Research on teacher learning: Studying how teachers' knowledge changes. Action in Teacher Education, 10(2), 7-24.

Baxter Magolda, M. (1992). Knowing and reasoning in college: Gender-related patterns in students' intellectual development. San Francisco: Jossey-Bass.

Boz, Y., \& Uzuntiryaki, E. (2006). Turkish prospective chemistry teachers' Beliefs about chemistry teaching. International Journal of Science Education, 28(14), 1647-1667.

Bozdoğan, A. E., Aydın, D., \& Yıldırım, K. (2007). Attitudes of teacher candidates towards teaching profession. Kırşehir Faculty of Education Journal, 8(2), 83-97.

Brownlee, J. (2001). Beliefs about knowing in pre-service teacher education students. Higher Education Research Development, 20(3), 281-291.

Chan, K.W., \& Elliot, R.G. (2004). Relational analysis of personal epistemology and conceptions about teaching and learning. Teaching and Teacher Education, 20, 817-831.

Çepni, S. (2018). Introduction to research and project studies (8th ed.). Author's Own Publication, Trabzon.

Çocuk, H. E., Yokuş, G., \& Tanrıseven, I. (2015). Pedagogical formation students' self-efficacy and metaforic perceptions related to teaching profession. Mustafa Kemal University Journal of Graduate School of Social Sciences, 12(32), 373-387.

Demir, S., \& Akınoğlu, O. (2010). Epistemological beliefs in teaching learning processes. Atatürk Faculty of Education Journal of Educational Sciences, 32, 75-93.

Deryakulu, D. (2004). Epistemological beliefs (Editörler: Y. Kuzgun and D. Deryakulu). Individual Differences in Education (ss.259-287). Ankara: Nobel Publishing-Distribution.

Ernest, P. (1989). The impact of beliefs on the teaching of mathematics. Paper prepared for ICME VI, Budapest Hungary.

Ersoy, Y. (2006). Innovations in mathematics curricula of elementary schools-I: Objective, content and acquisition. Elementary Education Online, 5(1), 30-44. 
Fennema, E. F., \& Franke, M. L. (1992). Teachers' knowledge and its impact. In D. Grouws (Eds.), Handbook of Research on Mathematics Teaching and Learning (pp. 147-164). New York: Macmillan.

Frykholm, J. (2003). Teachers' tolerance for discomfort: Implications for curricular reform in mathematics. Journal of Curriculum \& Supervision, 19(2), 125-149.

Goulding, M., Rowland, T., \& Barber, P. (2002) 'Does it matter? Primary teacher trainees' subject knowledge in mathematics. British Educational Research Journal, 28(5), 689-705.

Gronlund, N. E., \& Linn, R. L. (1990). Measurement and evaluation in teaching (6th ed.). New York, NY: MacMillan.

Grossman, P. L. (1990). The making of a teacher: Teacher knowledge and teacher education. New York: Teachers College Press.

Güneş, G. (2008). Reflection on new primary school mathematics curriculum on the teaching and learning environment (Unpublished Phd Dissertation). Karadeniz Technical University, Trabzon.

Gürbüztürk, O., \& Genç, S. Z. (2004). Teacher candidates' views on teaching profession. Inonu University Journal of the Faculty of Education, 5(7), 47-62.

Güven, M., \& Belet, Ş. D. (2010). Primary school teacher trainees' opinions on epistemological beliefs and metacognition. Elementary Education Online, 9(1), 361-378.

Hill, H. C., Schilling, S. G., \& Ball, D. L. (2004). Developing measures of teachers' mathematics knowledge for teaching. The Elementary School Journal, 105(1), 11-30.

Huckstep, P., Rowland, T., \& Thwaites, A. (2002). Primary teachers' mathematics content knowledge: What does it look like in the classroom? British Educational Research Association Annual Conference, University of Exeter, 12-14 Sept.

Karasar, N. (2019). Scientific research method: Concepts principles techniques (34th ed.). Nobel Academic Publishing, Ankara.

Köğce, D., Yıldız, C., \& Aydın, M. (2010). Teacher role and teaching profession according to primary mathematics teacher candidates, 9th Mathematics Symposium Pictures and Festivals, 20-22 Ekim, Trabzon.

Lloyd, G., \& Wilson, S. (1998). Supporting innovation: The impact of a teacher's conceptions of functions on his implementations of a reform curriculum. Journal for Research in Mathematics Education, 29(3), 248-274.

Merriam, S. B. (1988). Case study research in education: A qualitative approach. San Francisco, C.A: Jossey-Bass.

Miles, M., \& Huberman, M. (1994). An expanded source book qualitative data analysis (2nd ed.). America: Person Education.

Morgil, F. İ., \& Y1lmaz, A. (1999) Tasks and qualifications of science teacher, suggestions for training science teachers. Hacettepe University Faculty of Education Journal, 15, 181-186.

Nespor, J. (1987). The role of beliefs in the practice of teaching. Journal of Curriculum Studies, 19, $317-328$.

Özoğlu, M. (2010). Problems of teacher education system in Turkey. Seta Analysis, 17, 1-35.

Pajares, M. F. (1992). Teachers' beliefs and educational research: Cleaning up a messy construct. Review of Educational Research, 62(3), 307-332.

Shulman, L. S. (1987). Knowledge and teaching: Foundations of the new reform. Harvard Educational Review, 57(1), $1-22$.

Sinan, O., \& Akyüz, G. (2012). Prospective elementary mathematic teachers' beliefs about teaching mathematics. Mustafa Kemal University Journal of Social Sciences Institute, 9(17), 327-346.

Tepeli, Y., \& Caner, M. (2014). Teacher certificate program students' opinions on teaching practice. Journal of Educational Sciences Research, 4(2), 313-328.

Thompson, A. G. (1992). Teachers' belief and conceptions: A synthesis of there search. In D. A. Grouws (Ed.), Handbook of research on mathematics teachingand learning (s.127-146), New York: Macmillian.

Tsai, C. (2002). Nestedepistemologies: Scienceteachers' beliefs of teaching, learningandscience. International Journal of ScienceEducation, 24(8), 771-783.

Tunca, N. (2012). Developing the professional values scale for primary education teachers and determining the 
professional values of primary education teachers (Unpublished Phd Dissertation). Anatolian University, Eskişehir.

Ünüvar, S. (2012). Faculties of arts and sciences and the formation program (Teacher Training). Education and Society Journal in the 21st Century, 1(2), 97-104.

Whitmire, E. (2003). Epistemological Beliefs and The Information-Seeking Behavior of Undergraduates. Library and Information Science Research, 25, 127-142.

Wilkins, J., \& Brand, B. (2004). Change in pre-service teachers' beliefs: An evaluation of a mathematics methods course. School Science \& Mathematics, 104(5), 226-232.

Yapıcı, M., \& Yapıcı, Ş. (2013). Teacher Candidates' Metaphors About Pedagogical Formation. Turkish Studies, 8(8), 1421-1429.

Yıldırım, A., \& Şimşek, H. (2018). Qualitative research methods in the social sciences (11th ed.). Seçkin Publishing: Ankara.

Yıldırım, İ., \& Vural, Ö. F. (2014). Problems related with teacher training and pedagogical formation in Turkey. Journal of Teacher Education and Educators, 3(1), 73-90.

Yin, R. K. (1994). Case study research design and methods (2nd ed.). Thousand Oaks, CA: Sage Publications.

Yüksel, S. (2011) Thoughts of faculty of arts and sciences regarding teacher training system (example of Uludağ University Faculty of Science and Letters). Educational Sciences in Theory and Practice, 11(1), 179-198.

\section{Note}

A short version of this study was presented in Turkish Computer and Mathematics Education Symposium-2 in Adiyaman University, Turkey, in 2015. 